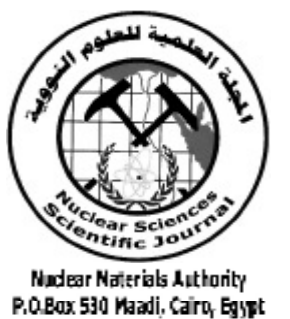

ISSN 2314-5609

Nuclear Sciences Scientific Journal

$7,125-133$

2018

http://www.ssnma.com

\title{
OCCURRENCE AND MINERAL CHEMISTRY OF ISHIKAWAITE IN THE MINERALIZED PEGMATITES OF GABAL SAMMA, SOUTHEASTERN SINAI, EGYPT
}

\author{
MOHAMED O. EL-HUSSEINY \\ Nuclear Materials Authority, P. O. Box 530 El-Maadi, Cairo, Egypt
}

\begin{abstract}
The occurrence and mineralogical characteristics of ishikawaite in unzoned pegmatite hosted in the monzogranite of Gabal Samma area, Southeastern Sinai, Egypt are investigated. Ishikawaite occurs in highly radioactive pegmatitic bodies in which the averages of uranium and thorium contents are $(211 \& 1480$ ppm respectively). The mineral presents in association with uranophane, thorite, uranothorite, columbite, betafite, metamict zircon and fluorite. The pegmatites occur as pockets $(5 \times 10 \mathrm{~m})$ and dykes $(1 \times 20 \mathrm{~m})$ hosted in the monzogranites. The investigated mineral is generally black to dark brown in color, forming anhedral grains with a black to brown streak and opaque with vitreous luster.

The mineralogy and geochemistry of the studied ishikawaite were determined using microscopic examination as well as quantitative analysis by ICP-MS. The ICP-MS shows the average oxides composition: $47.61 \% \mathrm{Nb}_{2} \mathrm{O}_{5}, 22.83 \% \mathrm{UO}_{2}, 6.06 \% \mathrm{Fe}_{2} \mathrm{O}_{3}, 5.44 \% \mathrm{Ta}_{2} \mathrm{O}_{5}, 4.69 \% \mathrm{REE}_{2} \mathrm{O}_{3}, 4.34 \% \mathrm{ThO}_{2}, 3.23 \% \mathrm{CaO}$ and $2.99 \% \mathrm{Y}_{2} \mathrm{O}_{3}$. The minor to trace elements include $\mathrm{Mn}$, Ti, $\mathrm{Al}$ and $\mathrm{Zr}$. The calculated empirical formula is $\left(\mathrm{U}_{0.231} \mathrm{Th}_{0.045} \mathrm{Fe}^{+3}{ }_{0.207} \mathrm{Ca}_{0.157} \mathrm{Y}_{0.071} \mathrm{REE}_{0.06} \mathrm{Mn}_{0.048} \mathrm{Al}_{0.021} \mathrm{Na}_{0.015} \mathrm{~K}_{0.007} \mathrm{Zr}_{0.007} \mathrm{Mg}_{0.002} \mathrm{Hf}_{0.001}\right)_{\Sigma 0.883}\left(\mathrm{Nb}_{0.976}\right.$ $\left.\mathrm{Ta}_{0.067} \mathrm{Ti}_{0.028}\right)_{\sum 1.071} \mathrm{O}_{4}$. The simplified formula is $\left(\mathrm{U}, \mathrm{Th}, \mathrm{Fe}^{+3}, \mathrm{Ca}, \mathrm{Y}, \mathrm{REE}\right)(\mathrm{Nb}, \mathrm{Ta}, \mathrm{Ti}) \mathrm{O}_{4}$. The formula of the study ishikawaite is non stoichiometric and show some deficiency in the A-site relative to the B-site. Metamictization, a common feature of ishikawaite is suspected to be the main reason for this deviation from ideal stoichiometry.

The deviations of $\mathrm{Y} / \mathrm{Ho}$ and $\mathrm{Zr} / \mathrm{Hf}$ ratios of the investigated ishikawaite from chondiritic trace-element ratios are characteristic for strong magmatic with hydrothermal alteration.

\section{INTRODUCTION}

Samarskite-group minerals having general formula $\left(\mathrm{A}^{3+} \mathrm{B}^{5+} \mathrm{O}_{4}\right)$ where A represents $\mathrm{Fe}, \mathrm{Ca}$, REE, Y, $\mathrm{U}$ and $\mathrm{Th}$, while $\mathrm{B}$ represents $\mathrm{Nb}$, $\mathrm{Ta}$ and $\mathrm{Ti}$ can be classified into: samarskiteY, calciosamarskite and ishikawaite. The only significant difference between samarskite-Y, ishikawaite and calciosamarskite lies in the occupancy of the A-site. The A-site of samarskite- $\mathrm{Y}$ is dominated by $\mathrm{Y}+\mathrm{REE}$ whereas the

A-site of ishikawaite is dominantly $\mathrm{U}+\mathrm{Th}$ and calciosamarskite is dominantly Ca. Also, ishikawaite is depleted in light rare earth elements (LREE) and enriched with heavy rare earth elements (HREE) (Hanson et al. 1999). Due to its very complex chemical composition, occurrence in metamict state and frequent pervasive alteration, the definition of samarskite and description of its crystal structure has always been a challenge (Tomasic et al., 2010).
\end{abstract}


Kimura (1922) was the first one who described ishikawaite $(\mathrm{U}, \mathrm{Fe}, \mathrm{Y}, \mathrm{Ca})(\mathrm{Nb}, \mathrm{Ta})$ $\mathrm{O}_{4}$ as U-rich, REE-poor mineral. After two years, Ohashi (1924) stated that, there is a crystallographic relationship exists between ishikawaite and samarskite. Cerny and Ercit (1989) considered ishikawaite as a probable U-rich samarskite. Warner and Ewing (1993) proposed that samarskite is an $\mathrm{A}^{3+} \mathrm{B}^{5+} \mathrm{O}_{4}$ mineral with an atomic arrangement related to $\alpha$ $\mathrm{PbO}_{2}$, where B-site contains $\mathrm{Nb}, \mathrm{Ta}$ and Ti and the A-site contains all other cations.

Hanson et al. (1999) stated that samarskite -group minerals should include only those that have $\mathrm{Nb}>\mathrm{Ta}$ and $\mathrm{Ti}$ in the B-site. The X-ray diffraction analysis of the recrystallized type specimen of ishikawaite reveal that they have the same structure as samarskite-Y recrystallized at high temperature.

In Egypt, Raslan (2008) reported the presence of ishikawaite in the mineralized Abu Rushied Gneiss, South Eastern Desert. Ishikawaite mineral is associated with columbite, Hf-rich zircon and dark Li-mica mineral.

This study presents genuine data on the mineral chemistry of the ishikawaite occurring in the pegmatitic bodies hosted in the monzogranite of Gabal Samma area. The available data may contribute significantly to the genesis of the mineral.

\section{GEOLOGIC SETTING}

Gabal Samma area is delineated by Latitudes $28^{\circ} 9^{\prime}$ and $28^{\circ} 11^{\prime} \mathrm{N}$. Longitudes $34^{\circ} 8$ and $34^{\circ} 15^{\backslash}$ E. (Fig. 1). Gabal Samma is an oval shaped pluton consisting of monzogranites trending E-W direction. Generally, these monzogranites intrude gneisses and migmatites and older granitoids with sharp contacts. The pegmatites present in the monzogranite and concentrated along the pluton periphery (Abd Allah,1995 \& Nasr, 2006). The monzogranites are hard, massive, medium-, to coarsegrained, grey to pink in color and are rich in black mafic minerals. They are characterized by cavernous weathering and intensive joints taking four trends. The most dominant trends are NW-SE and NE-SW, while N-S and E-W are subordinate. The monzogranites are traversed by dykes varying in composition from acidic to basic and trending mainly to NE-SW direction beside subordinate NW-SE direction (Ahmed, 1985). Petrographically, monzogranite is composed mainly of plagioclases, quartz, $\mathrm{K}$-feldspars and biotite. Plagioclases occur as euhedral crystals twinned according to albite law. They are present in two sizes, mediumsized crystals of oligoclase and fine-sized albite crystals. Some of the phenocrysts exhibit discontinuous lamellar twinning and dissected by cracks filled with iron oxides. Quartz occurs as fine crystals accompanying albite in the ground mass or included in the recrystallyzed oligoclase and as medium crystals associating the other constituents. Potash feldspars occur as subhedral crystals of string perthite. Mica minerals represent about $4 \%$ of the rock occurring as flakes of biotite occasionally enriched by iron oxides (ferribiotite) and characterized by pleochroic halos around minute crystals of zircon. Accessory minerals are mainly sphene and zircon. The sphene crystals are either primary characterized by sphenoidal shape or secondary with undefined forms and associating opaque minerals. Zircon is partially metamectized with obvious clouded colors, mostly yellow to grey, due to wide spreading of the radioelements. They are also zoned and fractured exhibiting radial fractures.

The pegmatites are unzoned and occurring as pockets and dykes hosted in monzogranite of Gabal Samma. They are very coarse -grained and have pink color. The pockets vary in size from 0.3 to $10 \mathrm{~m}$ in length and from 0.2 to $5 \mathrm{~m}$ in width in addition to several small pockets of size varying from 25 to 75 $\mathrm{cm}$ in length and 10 to $25 \mathrm{~cm}$ in width. The pegmatitic dykes have thickness vary from 25 to $75 \mathrm{~cm}$ and extend for about $20 \mathrm{~m}$. Three pegmatitic anomalies are recorded in the pegmatitic bodies hosted in the monzogranite of Gabal Samma. The radiometric measurements 


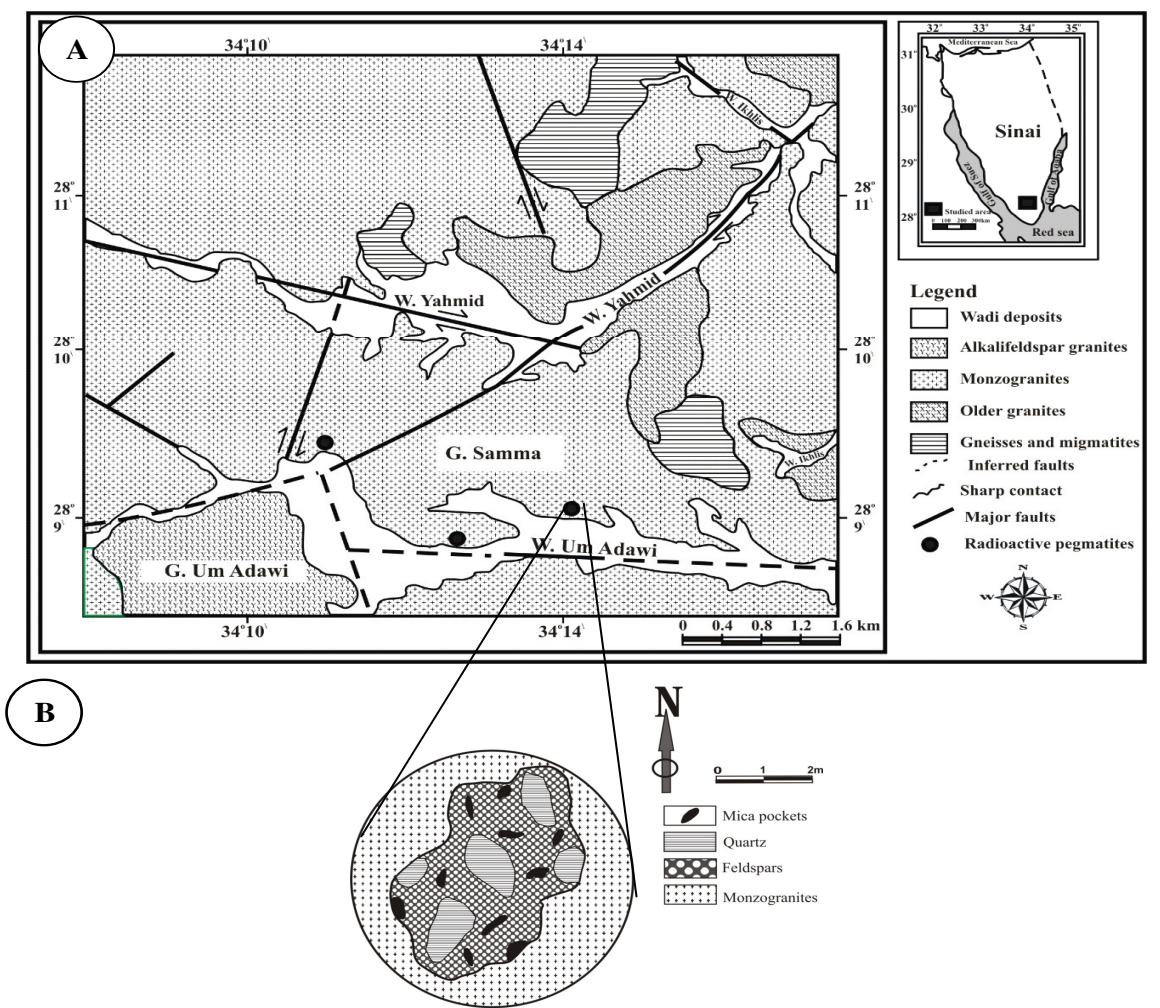

Fig.1: A) Geological map of Gabal Samma (after Nasr, 2006)

B) Sketch showing the mode of occurrence of pegmatite pocket

of these pegmatitic anomalies using Gamma spectrometer technique show that the average of the uranium and thorium contents in these anomalies are $211 \& 1480 \mathrm{ppm}$ respectively. Samarskite, columbite, thorite, uranothorite, betafite, metamict zircon and fluorite are the accessory minerals (Nasr, 2006).

\section{METHODOLOGY}

Representative 5 mineralized samples were collected from the radioactive pegmatites of Gabal Samma. The samples were crushed, ground, sieved and then were subjected to heavy liquid separation process using bromoform ( $\left.\mathrm{sp} . \mathrm{gr}=2.85 \mathrm{gm} / \mathrm{cm}^{3}\right)$. The pure individual ishikawaite grains were handpicked and investigated under the binocular microscope. The identification of the picked mineral was carried out by X-ray diffraction technique (XRD) using unit Philips PW-3710 with generator PW-1830, Cu target tube and $\mathrm{Ni}$ filter at $40 \mathrm{Kv}$ and $30 \mathrm{~mA}$ at the Egyptan Nuclear Materials Authority labs.

Semi-quantitative analysis was carried out by the Environmental Scanning Electron Microscope (ESEM) supported by Energy Dispersive Spectrometer unit (EDS) model Phillips XL at the Egyptian Nuclear Materials Authority Labs. The analytical conditions were 25-30 Kv accelerating voltages, 1-2 micron beam diameter and 60-120 second counting 
times. Minimum detectable weight concentration of elements ranges from 0.1 to $1 \mathrm{wt} \%$. The quantitative analysis of ishikawaite was further carried out by Inductively Coupled Plasma Mass Spectrometry (ICP-MS) at the Acme Labs, Vancouver, Canada. About 5 gm of the picked mineral was ground in an agate mortar to 200 mesh size. The samples were fused with $\mathrm{LiBO} 2$ digested and analyzed using the ICP-MS. The analytical precision monitored by international rock standards is found to be better than $\pm 7 \%$ for rare earth elements (REE) and with 5-10\% for trace elements and $\pm 2 \%$ for major oxides.

\section{MICROSCOPIC INVESTIGATION}

The mineral occurs as black to dark brown anhedral grains with a black to brown streak (Fig.2). Ishikawaite is opaque with vitreous luster. Cleavage and parting are absent because it is completely metamict. The resulting metamict state is due to the recoiling destruction of $U$ and Th for the crystal structure (Tomasic et al., 2008). The destruction of a mineral crystal lattice in a metamict mineral is reflected in its physical properties. Usually, this

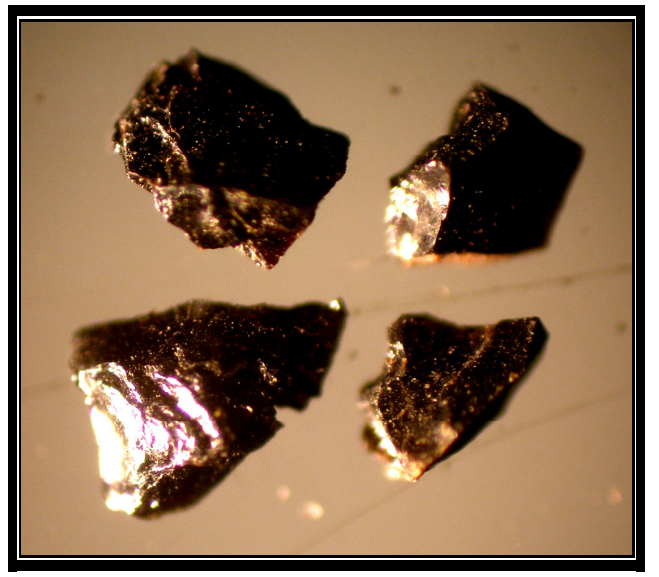

Fig.2: Anhedral ishikawaite grains, binocular microscope means a decrease in the density, the hardness, the birefringence and the refraction indices for metamict minerals.

The hardness of the study ishikawaite ranges from 5 to 6 and the specific gravity is $6.3 \mathrm{gm} / \mathrm{cm}^{3}$. Due to pervasive alteration and advanced metamictization of the mineral, the sample shows no diffraction peaks in the $\mathrm{X}$-ray diffraction study. So, the sample was recrystallized by heating to a tempreature of $1100{ }^{\circ} \mathrm{C}$ for 12 hours in reducing conditions. Figure (3) shows the XRD pattern of the recrystallized mineral.

\section{CHEMICAL COMPOSITION}

Several crystals of ishikawaite were subjected to semi-quantitative analyses using an Environmental Scanning Electron Microscope (ESEM). The EDX revealed that the ishikawaite crystals are characteristically enriched in $\mathrm{Nb}_{2} \mathrm{O}_{5}, \mathrm{UO}_{2}, \mathrm{Fe}_{2} \mathrm{O}_{3}, \mathrm{Ta}_{2} \mathrm{O}_{5}, \mathrm{TiO}_{2}$, $\mathrm{ThO}_{2}, \mathrm{CaO}, \mathrm{Y}_{2} \mathrm{O}_{3}$ and traces of $\mathrm{MnO}$ (Table, 1 and Figs. $4 \& 5$ ).

However, 4 samples of ishikawaite were subjected to ICP-MS analysis and results are

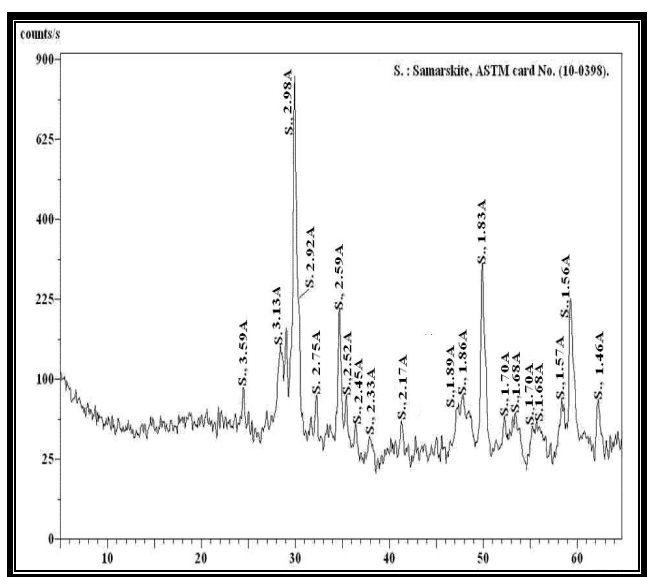

Fig.3: XRD pattern of samarskite grains 
Table 1: EDX analysis of ishikawaite

\begin{tabular}{lrrrrrrrrr}
\hline $\mathrm{Oxide}_{2}$ & $\mathrm{Nb}_{2} \mathrm{O}_{5}$ & $\mathrm{Ta}_{2} \mathrm{O}_{5}$ & $\mathrm{TiO}_{2}$ & $\mathrm{UO}_{2}$ & $\mathrm{ThO}_{2}$ & $\mathrm{Y}_{2} \mathrm{O}_{3}$ & $\mathrm{Fe}_{2} \mathrm{O}_{3}$ & $\mathrm{CaO}$ & $\mathrm{MnO}$ \\
\hline $\mathrm{Wt} \%$ & 43.33 & 5.9 & 4.13 & 23.79 & 3.92 & 2.14 & 5.08 & 7.66 & 0.97
\end{tabular}

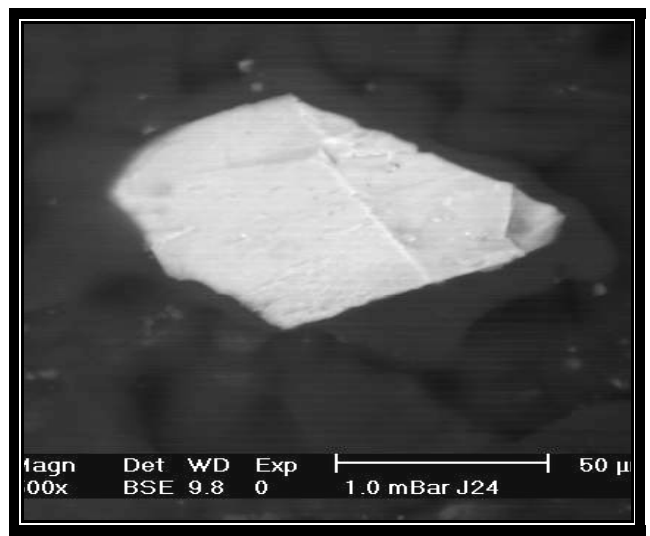

Fig.4: BSE image of ishikawaite

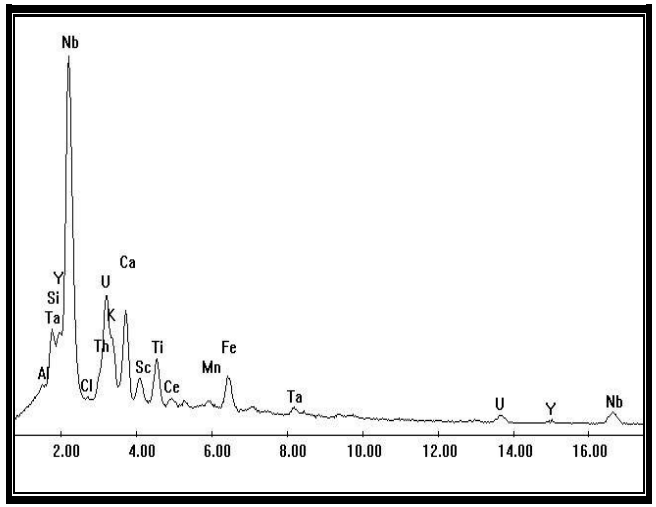

Fig.5: EDX spectrum of ishikawaite

given in Table (2) and Fig. (6). The analyzed data of the studied isikawaite were plotted on the ternary diagram of Hanson et al. (1999), which shows the A-site occupancy of samarskite-group minerals (Fig. 7). The figure shows that all the study samarskite samples lie in the ishikawaite field as they are U+Th dominant.
From the analytical data it is quite clear that the study mineral reflects the chemical composition of ishikawaite as indicated by the following evidences:

1- Both samarskite-Y and ishikawaite have a dominant $\mathrm{Nb}$ in the $\mathrm{B}$-site and the distinction between them must be based on the content of B-site occupancy. The obtained ICP-MS data revealed that $\mathrm{Nb}_{2} \mathrm{O}_{5}$ is the dominant in the study mineral, it ranges from 45.7 to 51.13 $\mathrm{wt} \%$ with an average of $47.61 \mathrm{wt} \%$. Thus, the study mineral falls actually within the compositional limits of both samarskite-Y and ishikawaite.

2- The samarskite group of minerals must comprise only those that have $\mathrm{NbT}$ a and $\mathrm{Ti}$ in the B-site (Hanson et al., 1999), and the investigated mineral contains an average $\mathrm{Ta}+\mathrm{Ti}=6.26 \mathrm{wt} \% \mathrm{Nb}=47.61 \mathrm{wt} \%$.

3- The study mineral is rich in both uranium and thorium where $U$ ranges from 20.65 to $25.67 \mathrm{wt} \%$ with an average of $22.83 \mathrm{wt} \%$, while Th contents vary from 3.4 to $5.86 \mathrm{wt} \%$ with an average of $4.34 \mathrm{wt} \%$ (Table 1). According to Hanson et al. (1999), the study mineral is U-rich samarskite (ishikawaite).

The study ishikawaite likes other samarskite-group minerals is enriched in HREE relative to LREE (Hanson et al. 1999), where the average of $\sum$ HREE is $3.73 \%$ compared with $0.96 \%$ for the $\sum$ LREE. The HREE enrichment of the study ishikawaite may be the result of fluorine preferentially complexing with the HREE relative to the LREE (Simmons et al., 2006). These authors have shown that the equilibrium constant for HREE fluoride complexes is greater than that for LREE fluoride complexes. Thus, it is likely that the HREE are preferentially incorporated into the late-stage fluids, which ultimately produce the mineralogy of the late-stage replacement units. High fluorine fugacity is manifested by the presence of fluorite as an accessory mineral in the pegmatite.

Oxide analyses are recalculated on the 
Table 2: Chemical analyses and chemical formulae of the study ishikawaite, Gabal Samma pegmatite

\begin{tabular}{|c|c|c|c|c|c|c|c|}
\hline & 1 & 2 & 3 & 4 & Average & $\mathbf{n}$ & $\mathrm{b}$ \\
\hline $\mathrm{Nb}_{2} \mathrm{O}_{5}$ & 45.7 & 51.13 & 47.12 & 46.5 & 47.61 & 49.49 & 37.8 \\
\hline $\mathrm{Ta}_{2} \mathrm{O}_{5}$ & 8.77 & 5.67 & 3.17 & 4.13 & 5.44 & 3.34 & 5.77 \\
\hline $\mathrm{TiO}_{2}$ & 0.68 & 0.87 & 0.95 & 0.78 & 0.82 & 0.35 & 0.45 \\
\hline $\mathrm{ThO}_{2}$ & 4.38 & 3.7 & 5.86 & 3.4 & 4.34 & 3.85 & 3.27 \\
\hline $\mathbf{U O}_{2}$ & 21.8 & 20.65 & 23.18 & 25.67 & 22.83 & 26.37 & 31.8 \\
\hline $\mathrm{Ca}_{2} \mathrm{O}_{3}$ & 0.13 & 0.12 & 0.10 & 0.15 & 0.13 & - & b.d.I. \\
\hline $\mathrm{Ce}_{2} \mathrm{O}_{3}$ & 0.12 & 0.11 & 0.12 & 0.13 & 0.12 & - & 0.1 \\
\hline $\mathrm{Pr}_{2} \mathrm{O}_{3}$ & 0.07 & 0.10 & 0.11 & 0.13 & 0.10 & - & 0.06 \\
\hline $\mathrm{Nad}_{2} \mathrm{O}_{3}$ & 0.36 & 0.22 & 0.28 & 0.24 & 0.28 & - & 0.56 \\
\hline $\mathrm{Sm}_{2} \mathrm{O}_{3}$ & 0.29 & 0.25 & 0.34 & 0.37 & 0.31 & - & 0.29 \\
\hline $\mathrm{Eu}_{2} \mathrm{O}_{3}$ & 0.02 & 0.02 & 0.02 & 0.03 & 0.02 & - & b.d.t. \\
\hline $\mathrm{Gad}_{2} \mathrm{O}_{3}$ & 0.97 & 0.92 & 0.95 & 1.06 & 0.98 & - & 1.17 \\
\hline $\mathrm{Tb}_{2} \mathrm{O}_{3}$ & 0.14 & 0.12 & 0.14 & 0.21 & 0.15 & - & 0.14 \\
\hline $\mathrm{Dy}_{2} \mathrm{O}_{3}$ & 0.85 & 0.89 & 0.95 & 1.28 & 0.99 & - & 0.85 \\
\hline $\mathrm{Ho}_{2} \mathrm{O}_{3}$ & 0.20 & 0.28 & 0.29 & 0.39 & 0.29 & - & 0.26 \\
\hline $\mathrm{Er}_{2} \mathrm{O}_{3}$ & 0.79 & 0.75 & 0.64 & 0.85 & 0.76 & - & 0.77 \\
\hline $\mathrm{Tm}_{2} \mathrm{O}_{3}$ & 0.13 & 0.11 & 0.13 & 0.19 & 0.14 & - & 0.09 \\
\hline $\mathbf{Y} \mathbf{b}_{2} \mathbf{O}_{3}$ & 0.27 & 0.24 & 0.21 & 0.28 & 0.25 & - & 0.17 \\
\hline $\mathrm{Lu}_{2} \mathrm{O}_{3}$ & 0.16 & 0.14 & 0.16 & 0.22 & 0.17 & - & 0.11 \\
\hline $\mathbf{Y}_{2} \mathbf{O}_{3}$ & 3.04 & 2.87 & 3.67 & 2.39 & 2.99 & 0.84 & 3.04 \\
\hline $\mathrm{ZrO}_{2}$ & 0.36 & 0.27 & 0.25 & 0.33 & 0.30 & 0.21 & 0.36 \\
\hline $\mathrm{HFO}_{2}$ & 0.10 & 0.04 & 0.08 & 0.09 & 0.08 & - & - \\
\hline Mno & 1.29 & 1.23 & 1.27 & 1.25 & 1.26 & 0.63 & 2.02 \\
\hline MgO & 0.01 & 0.05 & 0.04 & 0.01 & 0.03 & - & - \\
\hline CaO & 2.87 & 2.97 & 3.2 & 3.88 & 3.23 & 0.57 & 0.07 \\
\hline $\mathrm{Nan}_{2} \mathrm{O}$ & 0.16 & 0.14 & 0.19 & 0.17 & 0.17 & - & - \\
\hline $\mathrm{K}_{2} \mathrm{O}$ & 0.13 & 0.10 & 0.11 & 0.11 & 0.11 & - & - \\
\hline $\mathrm{Al}_{2} \mathrm{O}_{3}$ & 0.42 & 0.41 & 0.43 & 0.25 & 0.38 & - & - \\
\hline $\mathrm{Fe}_{2} \mathrm{O}_{3} \mathrm{t}$ & 6.48 & 5.45 & 6.00 & 6.30 & 6.06 & 12.51 & 8.9 \\
\hline Total & 100.69 & 99.82 & 99.96 & 100.79 & 100.32 & 100.01 & 100.3 \\
\hline$\sum$ REEE & 4.50 & 4.27 & 4.44 & 5.53 & 4.69 & 0.15 & 4.57 \\
\hline$\sum$ LREE & 0.99 & 0.82 & 0.97 & 1.05 & 0.96 & & \\
\hline ¿HREE & 3.51 & 3.45 & 3.47 & 4.48 & 3.73 & & \\
\hline \multicolumn{8}{|c|}{ 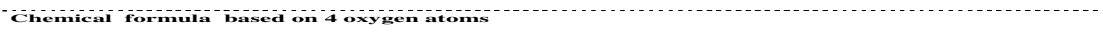 } \\
\hline Nb & 0.941 & 1.029 & 0.973 & 0.961 & 0.976 & 1.00 & 0.854 \\
\hline Ta & 0.109 & 0.069 & 0.039 & 0.051 & 0.067 & 0.03 & 0.078 \\
\hline $\mathbf{T i}$ & 0.023 & 0.029 & 0.033 & 0.027 & 0.028 & o.o1 & 0.017 \\
\hline Sum B & 1.073 & 1.127 & 1.045 & 1.039 & 1.071 & 1.04 & 1.048 \\
\hline Th & 0.045 & 0.038 & 0.061 & 0.035 & 0.045 & 0.04 & 0.037 \\
\hline U & 0.221 & 0.205 & 0.236 & 0.261 & 0.231 & 0.28 & 0.354 \\
\hline La: & 0.002 & 0.002 & 0.002 & 0.003 & 0.002 & - & o \\
\hline ce & 0.02 & 0.002 & $\mathbf{0 . 0 0 2}$ & 0.002 & 0.002 & - & 0.002 \\
\hline Pr & 0.001 & 0.002 & 0.002 & 0.002 & 0.002 & - & 0.001 \\
\hline Na & 0.006 & $\mathbf{0 . 0 0 4}$ & 0.005 & 0.004 & 0.005 & - & 0.010 \\
\hline $\mathrm{sm}$ & 0.005 & 0.004 & 0.005 & 0.006 & 0.005 & - & 0.00s \\
\hline Eu & 0.000 & $\mathbf{0 . 0 0 0}$ & $\mathbf{0 . 0 0 0}$ & O.ooo & $\mathbf{0 . 0 0 0}$ & - & o \\
\hline Gd & 0.015 & 0.014 & 0.015 & 0.016 & 0.015 & - & 0.019 \\
\hline $\mathbf{T b}$ & 0.002 & 0.002 & 0.002 & 0.003 & 0.002 & - & 0.002 \\
\hline Dy & 0.013 & 0.013 & 0.014 & 0.019 & 0.015 & - & 0.014 \\
\hline Ho & 0.003 & 0.004 & 0.004 & 0.006 & 0.004 & - & 0.004 \\
\hline Er & 0.011 & 0.011 & 0.009 & 0.012 & 0.011 & - & 0.012 \\
\hline $\mathbf{T m}$ & 0.002 & 0.002 & 0.002 & 0.003 & 0.002 & - & 0.001 \\
\hline $\mathbf{Y b}$ & 0.004 & 0.003 & 0.003 & 0.004 & 0.004 & - & 0.003 \\
\hline Lu & 0.002 & 0.002 & 0.002 & 0.003 & 0.002 & - & 0.002 \\
\hline $\mathbf{Y}$ & 0.074 & 0.068 & o.o89 & 0.058 & 0.071 & 0.02 & 0.081 \\
\hline$z_{r}$ & 0.008 & 0.006 & 0.006 & 0.007 & 0.007 & o.01 & 0.009 \\
\hline He & 0.001 & 0.001 & 0.001 & 0.001 & 0.001 & - & - \\
\hline Mn & o.oso & 0.046 & 0.049 & 0.048 & 0.048 & 0.02 & 0.086 \\
\hline $\mathbf{M g}$ & 0.001 & $\mathbf{0 . 0 0 3}$ & $\mathbf{0 . 0 0 3}$ & $\mathbf{0 . 0 0 1}$ & 0.002 & - & - \\
\hline $\mathrm{Ca}$ & 0.140 & 0.142 & 0.157 & 0.190 & 0.157 & 0.03 & 0.004 \\
\hline $\mathrm{Na}$ & 0.014 & 0.012 & 0.017 & 0.015 & 0.015 & - & 0.003 \\
\hline $\mathbf{K}$ & 0.008 & 0.006 & 0.006 & 0.006 & 0.007 & - & - \\
\hline AI & 0.023 & 0.022 & 0.023 & 0.014 & 0.021 & - & 0.013 \\
\hline Fe & 0.222 & 0.183 & 0.206 & 0.217 & 0.207 & 0.46 & 0.262 \\
\hline Sum A & 0.875 & 0.798 & 0.921 & 0.936 & 0.883 & 0.985 & 0.952 \\
\hline Zr/HF & 8.00 & 6.00 & 6.00 & 7.00 & 6.75 & - & - \\
\hline Y/Ho & 24.67 & 17.00 & 22.25 & 9.67 & 18.40 & - & - \\
\hline
\end{tabular}

a-Average of 4 microprob analyses of Abu Rushied ishikawaite samples (Raslan, 2008)

b-Average of 8 microprob analyses of Ishikawa, Japan, samples (Hanson et al., 1999) 


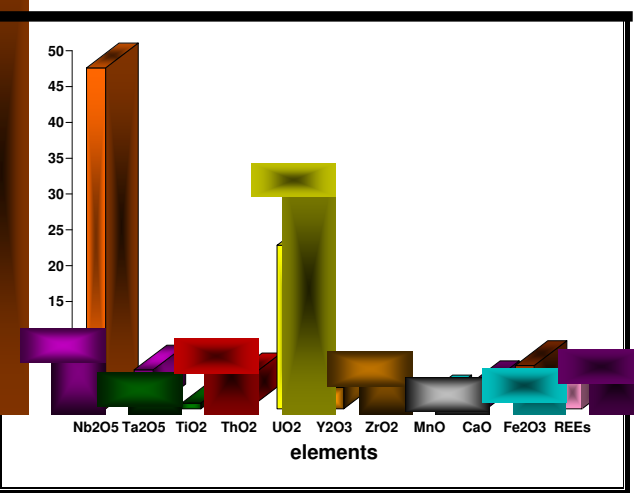

Fig.6: The chemical composition of the investigated ishikawaite as obtained by ICPMS

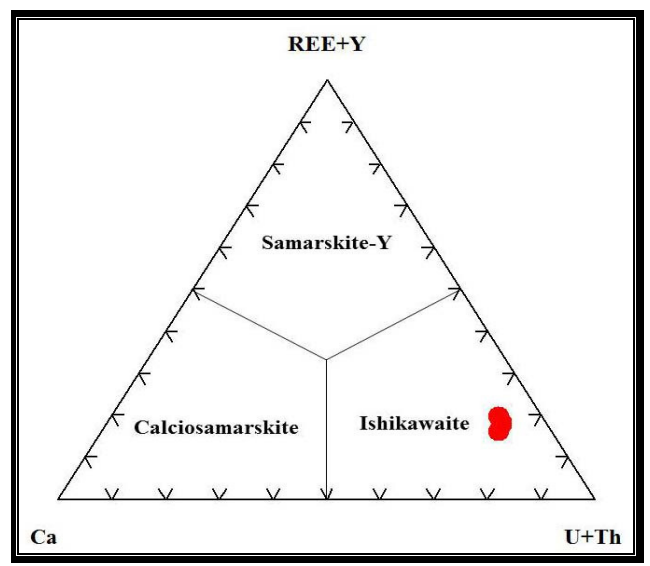

Fig.7:Ternary diagram showing A-site occupancy of samarskite-group minerals, After Hanson et al. (1999)

basis of 4 oxygens where $\mathrm{Nb}, \mathrm{Ta}$ and $\mathrm{Ti}$ are assigned to the B-site and $\mathrm{U}, \mathrm{Th}, \mathrm{Y}, \mathrm{Fe}, \mathrm{Ca}$, $\mathrm{Mn}$ and REE are occuping the A-site (Table 1). The empirical formula is $\left(\mathrm{U}_{0.231} \mathrm{Th}_{0.045} \mathrm{Fe}^{+3}\right.$ ${ }_{0.207} \mathrm{Ca}_{0.157} \mathrm{Y}_{0.071} \mathrm{Mn}_{0.048} \mathrm{Al}_{0.021} \mathrm{Na}_{0.015} \mathrm{~K}_{0.007}$ $\mathrm{Zr}_{0.007}^{0.207} \mathrm{Mg}_{0.002} \mathrm{Hf}{ }_{0.001}^{0.048} \mathrm{Gd}_{0.015}^{0.021} \mathrm{Dy}_{0.015}^{0.015} \mathrm{Er}_{0.011}^{0.007}$ $\mathrm{Sm}_{0.005} \mathrm{Nd}_{0.005} \mathrm{Ho}_{0.004} \mathrm{Yb}_{0.004} \mathrm{Lu}_{0.002} \mathrm{Tm}_{0.002}$ $\left.\left.\mathrm{Ce}_{0.002} \mathrm{La}_{0.002} \mathrm{Pr}_{0.002} \mathrm{~Tb}_{0.002}\right]\right)_{50.883}\left(\mathrm{Nb}_{0.976} \mathrm{Ta}\right.$ $\left.{ }_{0.067} \mathrm{Ti}_{0.028}\right)_{\sum 1.071} \mathrm{O}_{4}$. The simplified formula is

\section{(U, Th, $\left.\mathrm{Fe}^{+3}, \mathrm{Ca}, \mathrm{Y}, \mathrm{REE}\right)(\mathrm{Nb}, \mathrm{Ta}, \mathrm{Ti}) \mathrm{O}_{4}$.}

The formula of the study ishikawaite is non stoichiometric and show some deficiency in the A-site (A varies from 0.798 to 0.936 with an average of 0.883 ) relative to the B-site (B ranges from 1.039 to 1.127 with an average of 1.071). Metamictization, a common feature of ishikawaite is suspected to be the main reason for this deviation from ideal stoichiometry (Uher et al., 2009).

\section{DISCUSSION AND CONCLUSION}

The occurrence and physicochemical characteristics of ishikawaite in unzoned pegmatitic bodies hosted in the monzogranite of $\mathrm{Ga}$ bal Samma area, Southeastern Sinai, Egypt are investigated. The mineral occurs in a radioactive pegmatitic bodies in which the average of uranium and thorium contents are 211 and $1480 \mathrm{ppm}$ respectively. The mineral occurs in association with uranophane, thorite, uranothorite, columbite, betafite, metamict zircon and fluorite.

The investigated ishikawaite is generally black to dark brown in color, anhedral grains with a black to brown streak and opaque with vitreous luster.

The study ishikawaite shows clear decreasing in the $\mathrm{Zr} / \mathrm{Hf}$ ratio (vary from 6.00 to 8.00 with an average of 6.75) which is lower than the chondritic $\mathrm{Zr} / \mathrm{Hf}$ ratio $=38$ Anders and Grevesse (1989), this is characteristic for strong magmatic with hydrothermal alteration ( Bau, 1996, Irber, 1999, Geisler et al., 2003 and Rossi et al., 2011). Also, the average $\mathrm{Y} / \mathrm{Ho}$ ratio of the study mineral is 18.40 lower than the chondiritic $\mathrm{Y} / \mathrm{Ho}$ ratio $=28$ Anders and Grevesse (1989). Alteration is accompanied by pronounced deviation from the chondiritic Y/Ho ratio ( Van Dongen et al., 2010).

In conclusion, The study ishikawaite may be subjected to the hydrothermal alteration, after metamictization, because of metamic- 
tization leads to the volume expansion and consequent formation of the cracks. These fractures enhanced fluid flux and related interaction processes ( Zacek et al., 2009).

\section{REFERENCES}

Abd Allah, S. E., 1995. Geological studies on the basement rocks of south Lat. 28॰9\ Sinai, Egypt. Ph. D. Thesis, Zagazig Univ., Egypt, $345 \mathrm{p}$.

Ahmed, A. M., 1985. Geological studies of some granitic rocks around Wadi Um Adawi, Southeastern Sinai, Egypt. Ph. D. Thesis, Al-Azhar Univ., Cairo, Egypt, 164p.

Anders, E., and Grevesse, N., 1989. Abundances of the elements: Meteoritic and Solar. Geochimica et Cosmochimica Acta,53, 197-214.

Bau, M., 1996. Controls on the fractionation of isovalent trace elements in magmatic and aqueous systems: Evidence from $\mathrm{Y} / \mathrm{Ho}, \mathrm{Zr} / \mathrm{Hf}$ and lanthanide tetrade effect. Contributions to Mineralogy and Petrology, 123, 323-333.

Cerny, P., and Ercit, T. S., 1989. Mineralogy of niobium and tantalum: crystal chemical relationships, paragenitic aspects and their economic implications. In: Lanthanides, tantalum and niobium (Moller, P.; Cerny,P., and Saupe, F., Eds). Springer Verlag, Berlin, 27-79.

Geisler, T.; Pidgeon, R. T.; Kurtz, R.; Van Bronswijk, W., and Schleicher, H., 2003. Experimental hydrothermal alteration of partially metamict zircon. American Mineralogist, 88, 1496-1513.

Hanson, S. L.; Simmons, W. B.; Falster, A. U.; Foord, E. E., and Lichte, F. E., 1999. Proposed nomenclature for samarskite-group minerals: new data on ishikawaite and calciosamarskite. Mineralogical Magazine, 63(1),27-36.

Irber, W., 1999. The lanthanide tetrade effect and its correlation with $\mathrm{K} / \mathrm{Rb}, \mathrm{Eu} / \mathrm{Eu}, \mathrm{Sr} / \mathrm{Eu}, \mathrm{Y} / \mathrm{Ho}$ and $\mathrm{Zr} / \mathrm{Hf}$ of evolving peraluminous granite suites. Geochimica et Cosmochimica Acta, 63, 489-508.
Kimura, K., 1922. Ishikawaite; a new mineral from Ishikawa, Iwaki. J. Geol. Soc. Tokyo, 29, 316320.

Lamarao, C. N.; Pinho, S. C. C.; Junior, A. L., and Galarza, M. A., 2012. Mineralogy and geochemistry of the Paleoproterozoic, tinmineralized Bom Jardim granite of the Velho Guilherme Suite, eastern Amazonian craton. J. South American Earth Sciences, 38, 159-173.

Mckeough, M. A.; Lentz, D. R.; Mcfarlane, Ch. R. M., and Brown, J., 2013. Geology and evolution of pegmatite-hosted U-Th REE-Y-Nb mineralization, Kulyk, Eagle and Karin lakes region, Wollaston Domain, northern Saskatchewan, Canada: examples of the dual role of extreme fractionation and hybridization processes. J. Geosciences, 58, 321-346.

Nasr, M. M., 2006. Geological and radioactive studies on the granitoid rocks, North Ras Mohamed area, South Sinai, Egypt. Ph. D. Thesis, Fac. Sci., Suez Canal Univ., 197p.

Ohashi, R., 1924. On Daiton sulfur, Arakawaite and ishikawaite. J. Geol. Soc. Tokyo, 31, 166-170.

Raslan, M. F., 2008. Occurrence of ishikawaite (Urich samarskite) in the mineralize Abu Rusheid Gneiss, Southeastern Desert, Egypt. Inter. Geol. Review, 50, 1132-1140.

Rossi, J. N.; Tosselli, A. J.; Basei, M. A.; Sial, A. N., and Baez, M., 2011. Geochemical indicators of metalliferous fertility in the carboniferous San Blas pluton, Sierra de Velsco, Argentina. Geol. Soc., London, special publications, 350, 175-186.

Simmons, W. B.; Hanson, S. L., and Falster, A. U., 2006. Samarskite-(Yb): A new species of the samarskite group from the Little Patsy pegmatite, Jefferson County, Colorado. The Canadian Mineralogist, 44, 1119-1125.

Tomasic, N.; Bermanec, V.; Gajovic, A., and Linaric, M. R., 2008. Metamict minerals: an insight into a relic crystal structure using XRD, Raman Spectroscopy, SAED and HRTEM. Croatic Chemica Acta, 81(2), 391-400. 
Tomasic, N.; Gajovic, A.; Bermanec, V.; Linaric, M. R.; Su, D., and Skoda, R., 2010. Preservation of the samarskite structure in a metamict ABO4 mineral: a key to crystal structure identification. Eur. J. Mineral., 22, 435-442.

Uher, P.; Ondrejka, M., and Konecny, P., 2009. Magmatic and post-magmatic Y-REE- Th phosphate, silicate and $\mathrm{Nb}$-Ta-Y-REE oxide minerals in A-type metagranite: an example from the Turcok massif, the Western Carpathians, Slovakia. Mineralogical Magazine, 73(6), 1009-1025.

Van Dongen, M.; Weinberg, R. F., and Tomkins,
A. G., 2010. REE-Y, Ti and P remobilization in magmatic rocks by hydrothermal alteration during $\mathrm{Cu}-\mathrm{Au}$ Deposit Formation. Economic Geology, 105, 763-776.

Warner, J. K., and Ewing, R. C., 1993. Crystal chemistry of samarskite. American Mineralogist, 78, 419-424.

Zacek, V.; Skoda, R., and Sulovsky, P., 2009. UTh-rich zircon, thorite and allanite-(Ce) as main carriers of radioactivity in the highly radioactive ultrapotassic melasyenite porphyry from the Sumava Mts., Moldanubian Zone, Czech Republic. J. Geosciences, 54, 343-354.

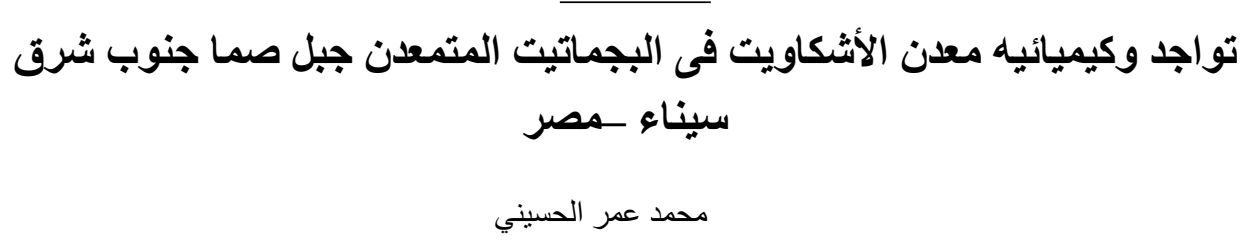

تم دراسة تو اجد معدن الأشكاويت وخصائصة المعدنيه و الكيميائية فى البجماتيت الغير ممنطق الموجود فى صخور المونزوجر انيت بجبل صما جنوب شرق سيناء ـمصر . ينو اجد البجماتيت فى شكل جيوب وقو اطع موجودة فى صخور المنزوجر انيت ـ يوجد معدن الأشكاويت فى صخور البجماتيت عالية

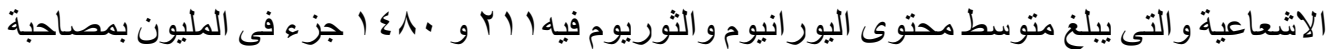

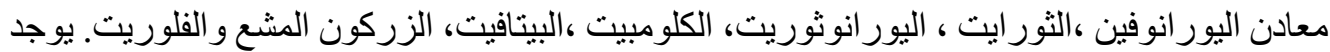
معدن الأشكاويت فى شكل حبيبات غير منتظمة الثكل يتر اوح لونها من الاسود الى البنى الغامق.

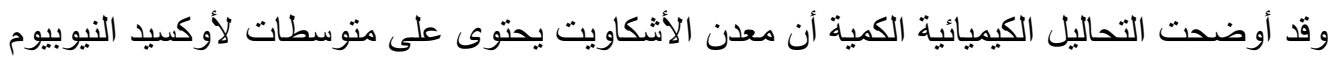

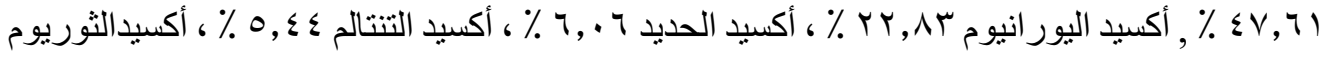

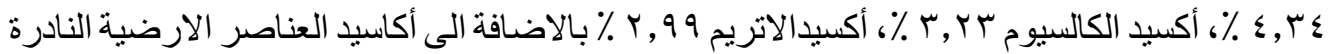
79 , ؟ ٪ مع وجود بعض العناصر الاخرى بكميات شحيحة مثل الزركونيوم و المنجانيز و الالمنيوم.

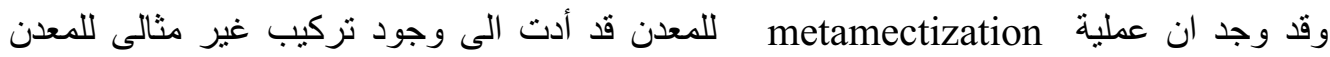
nonstoichometric فى الكوندريت وهذا دليل على تكون الأشكاويت من المراحل الاخيرة للمجما ونأثره بالمحاليل المائية 